\title{
Felismerési kísérlet az Emberi Jogok Európai Bírósága döntéseiben Fenyvesi Csaba* $^{*}$ Nyikos Attila $^{* *}$
}

A szerzők megvizsgálták, hogy az Emberi Jogok Európai Bírósága milyen iránymutatásokat fogalmazott meg döntéseiben a felismerésre bemutatásról. Milyen hibákat követtek el az egyes államok hatóságai a bizonyítási cselekmény körében és milyen következményei lettek az Emberi Jogok Európai Egyezménye megsértésének. Az írók megfogalmazták a magyar joggyakorlatot (nyomozást, bírósági bizonyítást) segítő jogi és kriminalisztikai javaslataikat is. Mindezt tették annak érdekében, hogy elkerüljük a téves, hibás felismerések legrosszabb következményét, a justizmordos döntés.

Kulcsszavak: felismerési kísérlet, Emberi Jogok Európai Bírósága, justizmord, hatósági hibák, Emberi Jogok Európai Egyezménye megsértése, krimináltaktika, megelőzés

\section{Identification parade in decisions of European Court of Human Rights}

The authors examined the following, lessoning decisions of European Court of Human Rights about identification parade. What kind of failures committed by national authorities in field of this proofing method and what consequences were violation of European Convention of Human Rights. The study-writers declared developing criminal procedural and criminalistical suggestions for the Hungarian investigators and judges. All these proposals were taken for prevention failured, defective identification and justizmord as its worst consequence.

Keywords: identity attempt, European Court of Human Rights, miscarriage of justice, wrongly sentenced, false conviction, authority's failures, violation of European Convention of Human Rights, criminaltactics, prevention

https://doi.org/10.32980/MJSz.2021.4.1255

\section{Az Emberi Jogok Európai Egyezménye és Bírósága}

utatásunk során áttekintettük az Emberi Jogok Európai Bírósága (a továbbiakban EJEB) határozatait a következő kérdések megválaszolása érdekében:

a) foglalkozik-e egyáltalán az EJEB a felismerésekkel („presentation for identification", "eyewitness identification procedure", „identification parade", "lineup")?

b) érinti-e bármelyik emberi alapjogot a felismerési eljárás?

\footnotetext{
* Egyetemi tanár, Pécsi Tudományegyetem, Állam- és Jogtudományi Kar.

** PhD-hallgató, Pécsi Tudományegyetem, Állam- és Jogtudományi Kar.
} 
c) ha igen, volt-e bármilyen megszegése?

d) melyek a leggyakoribb megszegési okok?

e) volt-e magyar felismerési anomália a bíróság előtt?

f) milyen következtetéseket, tanulságokat vonhatunk le a hazai szabályozásra, gyakorlatra?

Kiindulópontként megjelöljük, hogy Magyarország 1992. november 5-én ratifikálta, majd az 1993. évi XXXI. törvényben megfogalmazva 1993. április 7-én kihirdette az Európai Közösség egyik legfontosabb dokumentumát, "Az emberi jogok és alapvető szabadságok védelméről" szóló Egyezményt, amely eredetileg 1953. szeptember 3-án lépett hatályba. (A továbbiakban Egyezmény.) A ma már sok-sok kiegészítő jegyzőkönyvvel rendelkező Egyezmény sérelme - köztük a felismertetés hibái esetén bárki fordulhat panasszal a strasbourgi Európai Emberi Jogi Bírósághoz (European Court of Human Rights).

$\mathrm{Az}$ Egyezmény tartalmát és az EJEB eseteit áttekintve úgy véljük, hogy a témánkat leggyakrabban a 3 . Cikkben rögzített kínzás tilalma és a 6 . Cikkben található tisztességes eljáráshoz való jog érinti. (Utóbbi 1. pontja, mint alappillér jelenik meg a dokumentumban, mely mindenfajta eljárásra irányadó, míg a 2 . és 3. pontja a büntetőeljárásra tartalmaz elemeket. $)^{1}$

\section{Az Emberi Jogok Európai Bírósága felismerési döntései}

Az EJEB az - Európa Tanács tagjainak nagy többségében közvetlen hatállyal bíró Egyezmény legmagasabb szintú értelmező fóruma, döntései gyakran vezetnek

${ }^{1}$ Tanulmányunk bevezető részeként még bemutatjuk mindkét Cikket szó szerint:

„3. Cikk - Kínzás tilalma: Senkit sem lehet kínzásnak, vagy embertelen, megalázó bánásmódnak vagy büntetésnek alávetni."

„6. Cikk - Tisztességes tárgyaláshoz való jog:

1. Mindenkinek joga van arra, hogy ügyét a törvény által létrehozott független és pártatlan bíróság tisztességesen nyilvánosan és ésszerű időn belül tárgyalja, és hozzon határozatot polgári jogi jogai és kötelezettségei tárgyában, illetőleg az ellene felhozott büntetőjogi vádak megalapozottságát illetően. Az ítéletet nyilvánosan kell kihirdetni, a tárgyalóterembe történő belépést azonban meg lehet tiltani a sajtónak és a közönségnek a tárgyalás teljes időtartamára vagy egy részére annyiban, amennyiben egy demokratikus társadalomban ez az erkölcsök, a közrend, illetöleg a nemzetbiztonság érdekében szükséges, ha e korlátozás kiskorúak érdekei, vagy az eljárásban résztvevő felek magánéletének védelme szempontjából szükséges, illetőleg annyiban, amennyiben ezt a bíróság feltétlenül szükségesnek tartja, mert úgy ítéli meg, hogy az adott ügyben olyan különleges körülmények állnak fenn, melyek folytán a nyilvánosság az igazságszolgáltatás érdekeit veszélyeztetné.

2. Minden büncselekménnyel gyanúsított személyt mindaddig ártatlannak kell vélelmezni, amíg bünösségét a törvénynek megfelelően meg nem állapították.

3. Minden büncselekménnyel gyanúsított személynek joga van - legalább - arra, hogy

a) a legrövidebb időn belül tájékoztassák olyan nyelven, amelyet megért, és a legrészletesebb módon az ellene felhozott vád természetéről és indokairól;

b) rendelkezzék a védekezésének előkészítéséhez szükséges idővel és eszközökkel;

c) személyesen, vagy az általa választott védő segítségével védekezhessék, és ha nem állanak rendelkezésére eszközök védő díjazására, amennyiben az igazságszolgáltatás érdekei ezt követelik meg, hivatalból és ingyenesen rendeljenek ki számára ügyvédet;

d) kérdéseket intézzen vagy intéztessen a vád tanúihoz és kieszközölhesse a mentő tanúk megidézését és kihallgatását ugyanolyan feltételek mellett, mint ahogy a vád tanúit megidézik, illetve kihallgatják;

e) ingyenes tolmács álljon rendelkezésére, ha nem érti vagy nem beszéli a tárgyaláson használt nyelvet". 
jogszabály és joggyakorlat módosuláshoz. Ebből következően a felismertetéssel kapcsolatos döntései iránymutatóak lehetnek - álláspontunk szerint - és kell is lenniük belső jogunkra és annak alkalmazására. Ezért az elmúlt évtizedek bírósági határozatainak - felismerési aspektusú, nem kimeritő jellegü - időrendi áttekintése hasznos lehet a kezdeti kérdések megválaszolásában, a hatályos magyar szabályozás vizsgálatában, továbbá a "de lege ferenda" javaslatok megalkotásában.

Elsőként bemutatjuk a Perry Egyesült Királyság elleni² 2003-as ügyet, amelyben a rablások sorozatával gyanúsított kérelmező megtagadta a személyes felismerésen való részvételt, ezért egy magas rangú rendőrtiszt engedélyt adott, hogy róla rejtett filmfelvetélt készítsenek. Ez úgy történt, hogy a rendőrségi alkalmazottak felismerésre bemutatás céljából ismét behívták a hatóság épületébe a kérelmezőt, aki újfent megtagadta a felismerésre bemutatáson való részvételt. Ám amíg a közösségi térben várakozott, kamerával kristálytiszta felvételt készítettek róla. Majd videószalagot állítottak össze erről, mégpedig a kérelmezőn kívül 11 önkéntes felvételével együtt. Azután ezt a videót számos tanúnak bemutatták, akik közül kettő a kérelmezőt - bizonyos rablások elkövetőjeként - azonosította.

A kérelmező tárgyalásán a bíró elutasította a videós bizonyítékok kizárására irányuló kérelmét, bár elismerte, hogy a rendőrség nem tartotta be teljes mértékben az Eljárási Kódexet. A kérelmezőt elítélték, a fellebbezését pedig elutasították.

Az EJEB szerint a biztonsági kamerák szokásos használata, akár nyilvános utcán, akár olyan helyiségekben, mint például bevásárlóközpontok vagy rendőrkapitányságok, ahol törvényes és előrelátható célt szolgálnak, önmagában nem vet fel emberjogi problémás kérdést. Az ügyben azonban a rendőrség úgy állította be a biztonsági kamerát, hogy az tiszta felvételeket készítsen a kérelmezőről, és a felvételeket a tanúknak bemutatott montázsba illesztette az azonosítás céljából. A videót egyébként a nyilvános tárgyalás során is bemutatták. Függetlenül attól, hogy a kérelmező tudott-e a kameráról, nem volt semmi arra utaló jel, hogy azonosítási célokra készült volna bármiféle felvétel róla. A rendőrség által alkalmazott fogás túllépte a biztonsági kamerák szokásos vagy várható használatát, ezért a felvétel állandó rögzítése és további felhasználás céljából montázsba való felvétele a kérelmezővel kapcsolatos személyes adatok feldolgozásának vagy gyűjitésének tekinthető, ami meg már alapjogsértő.

Ezen kívül a felvételeket nem önkéntesen szerezték, vagy olyan körülmények között, ahol észszerüen számítani lehetett a felvételre és azonosítási célokra történő felhasználásra. Ebből következően a rendőrhatóság beavatkozott a magánélet tiszteletben tartásához való jogba, amivel megsértette az Egyezmény 8. Cikkét. $^{3} \mathrm{Az}$ Egyezmény 8. Cikkelye pontosan a következőket tartalmazza: „Magánés családi élet tiszteletben tartásához való jog. 1. Mindenkinek joga van arra, hogy magán- és családi életét, lakását és levelezését tiszteletben tartsák. 2. E jog gyakorlásába hatóság csak a törvényben meghatározott, olyan esetekben avatkozhat be, amikor az egy demokratikus társadalomban a nemzetbiztonság, a

\footnotetext{
${ }^{2} N^{\circ} 63737 / 00$, Judgement 17 July 2003

${ }^{3}$ Az egyhangúan kimondott emberjogi sértés mellett 1.500 euró nem vagyoni kártérítést és 9.500 euró költségtérítést ítélt meg a kérelmezőnek a Bíróság.
} 
közbiztonság vagy az ország gazdasági jóléte érdekében, zavargás vagy büncselekmény megelözése, a közegészség vagy az erkölcsök védelme, avagy mások jogainak és szabadságainak védelme érdekében szükséges."

Zashevi Bulgária elleni ügye két bolgár állampolgár, Genka Ivanova Zasheva asszony és Metodi Dimitrov Zashev 2005. április 26-án benyújtott kérelme alapján indult. ${ }^{4} \mathrm{~A}$ kérelmezők azt állították, hogy a hatóságok elmulasztották a hatékony nyomozást a fiúk halálával kapcsolatban, és hogy nem kaptak hatékony jogorvoslatot sem. A kérelmezők szülei Ivaylo Zashevnek, akit megöltek nagynénje házában Stavertsi faluban, Pleven régióban, 1997 februárjában. A búncselekmény úgy történt, hogy: éjfél körül az áldozat és testvére Valeri Zashev felébredt, és a szobában három férfit láttak, akik maszkot és kesztyút viseltek. A támadók megparancsolták a testvéreknek, hogy adják át a rendelkezésükre álló pénzt. Ekkor T. L., a gyermekek nagynénje belépett a szobába. A támadók ettől megriadtak, a fegyverrel rendelkező férfi két lövést adott le. Ezek közül a második eltalálta Ivaylo Zashev kisfiút, aki pár perccel később ennek következtében elhunyt.

A nyomozóhatóság kihallgatta T. L. asszonyt és számos más tanút. Köztük az egyik tanú V. K. volt, aki P. T. helyi üzletember személyi soförjeként dolgozott. Február 8-án azonban már gyanúsítottá vált és néhány napig őrizetben tartották. Ez alatt többször kikérdezték. Vallotta, hogy P. T utasította, hogy menjen I. K.-val és másik két személlyel Stavertsibe. Amikor a három ember kiszállt az autóból kesztyút és maszkot vettek fel. V. K. pár percet várt rájuk mialatt két lövést hallott. V. K. ezután visszatért P. T. házába, aki azt mondta neki, hogy felejtse el az éjszaka eseményeit. 1997. február 15-én P. T.-t, I. K.-t és V.P.-t letartóztatták, másnap azonban P. T.-t szabadon engedték, majd a nyomozó végrehajtott egy felismerésre bemutatást, ahol V. K. azonosította I. K.-t és V.P.-t. 1997. márciusában egy bizonyos G. G.-t is letartóztattak a rablásban való részvétel gyanújával. V.K.-t 1997 júniusában ismét kihallgatták. Visszavonta korábbi nyilatkozatait, és azt mondta, a rendőrség kényszerítette rá, hogy hamis bizonyítékokat szolgáltasson. Egy augusztusi kihallgatás során egy személy, akit őrizetbe vettek, és aki ugyanabban a cellában tartózkodott, mint G.G, állította, hogy ez a személy arra kérte, ölje meg V.K-t. 1997 novemberében a nyomozó újra kihallgatta V.K.-t, aki ismét megváltoztatta álláspontját. Megerősítette 1997-es februári nyilatkozatait, és visszavonta júniusi nyilatkozatát. Azt mondta, hogy azt a nyilatkozatát P.T nyomása alatt tette, aki elrabolta és egy hónapig fogva tartotta. 1997 decemberében szervezett felismerésre bemutatáson V.K. nem ismerte fel G. G.-t, majd kijelentette, hogy a rendőrség rosszul bánt vele és nyomást gyakoroltak rá, hogy egy előre meghatározott személyt azonosítson a felismerésre bemutatás során.

A Bíróság a $V$. $K$. részvételével lebonyolított felismerésre bemutatást nem találta megbízhatónak. Az eljárási szabályokkal ellentétben nem kérdezték meg az elkövetők egyes megkülönböztető jegyeiről, amelyekről azonosítanák őket a felismertetés elött, és nem is voltak olyan egyének a felsorakoztatottak sorában, akik hasonlítottak volna hozzá. Sőt, V. K. utasítást kapott, hogy kit és milyen fizikai jellemzők alapján azonosítson. Az ügyészség semmilyen más bizonyítékot nem

\footnotetext{
${ }^{4}$ Case of Zashevi v. Bulgaria (Application no. 19406/05) Judgement (final) 2 March 2011
} 
nyújtott be a gyanúsítottak és a büncselekmény közötti kapcsolat megteremtésére. Bizonyítékok hiányában felmentő ítélet született.

Az EJEB szerint a nyomozók elsősorban ott vétettek hibát, hogy a felismertetés lefolytatása elött nem gyüjtöttek elegendő olyan információt, amelyből megállapíthatták volna, hogy jelen esetben egy speciális, detektívtükörrel lefolytatott felismertetésre lett van szükség a szemtanú biztonsága és befolyásmentessége érdekében. Majd magát a cselekményt is több ponton szabálytalanul hajtották végre. Mindezek után pedig ott hátráltatták a nyomozás eredményességét és tisztességét azzal, hogy nem biztosítottak hatékony védelmet a kulcsfontosságú tanú számára, aki valószínúleg a kapott fenyegetések miatt visszavonta az összes terhelő kijelentését. A fentiekre tekintettel az EJEB arra a következtetésre jutott, hogy a nyomozás Ivaylo Zashev halálának ügyében megsértette az Egyezmény 2. Cikkét és marasztalta Bulgáriát (...violation of Article 2 of the Convention"). ${ }^{5}$

1999 decemberében a kérelmező mégis feljelentést tett, amelyben a három civil ruhás rendőr bíróság elé állítását kérte. A kérelmező leírta a két nap történéseit, amelyeket állitása szerint ugyanaz a három rendör követett el. A kérelmező továbbá megjegyezte, hogy az a rendőrtiszt, aki pisztolyt fogott a gyomrához magas és vékony volt, haja pedig vékonyszálú. 1999. december 27-én a kérelmező ismét nyilatkozatot tett fia tolmácsolásával, és állította, hogy két rendőr 18 óra körül a házához ment, akik elmondták, tudnak arról, hogy panaszt nyújtott be. Őket még sosem látta. Bementek a házába, összetépték az orvosi jelentéseit, összetörték a lányáról készült képet és tönkretették a zöld kártyáját. Ezután megfenyegették és megverték.

A kérelmező jelezte, hogy a rendőrségen neki bemutatott fényképek egyikén sem szerepelt az elkövető. Ezen kívül a kérelmező rövid leírást adott a két férfiról, és kijelentette, hogy mindkettőjük szakállas. Elmondása szerint az a tiszt, aki zsinórral fojtogatta magas és vékony volt, fehér bőrü és fekete hajú. 2000. március 31-én a kérelmezőt felhívták, hogy jelenjen meg egy felismerésre bemutatáson a rendőrségen. 108 rendőr lépett be (a terrorizmus elleni részlegből) az azonosító helyiségbe 10 fős csoportokban. Az azonosítási protokoll szerint a kérelmező és fia azonosította R. G.-t mint a házukba lépett emberek egyikét. Az ügyész ekkor viszont úgy döntött, hogy a kérelmező fiát ki kell vinni az azonosító helyiségből, mivel izgatottan viselkedett.

Miután a fiát kivitték, a kérelmező hölgy ismét kijelentette az ügyésznek, hogy R.G. egy volt, azok közül, akik 1999. november 28-án léptek be a házába. Azt is kijelentette, hogy R. G. és a két másik tiszt újságírónak vallotta magát, ezért

\footnotetext{
${ }^{5} \mathrm{~A}$ kérelmező részére 20.000 euró megfizetésére is kötelezte Bulgáriát az EJEB nem vagyoni kárként és 4.000 euróra pedig költségtérítésként. (Az Egyezmény 2. Cikke kimondja: „Élethez való jog1. A törvény védi mindenkinek az élethez való jogát. Senkit nem lehet életétől szándékosan megfosztani, kivéve, ha ez halálbüntetést kiszabó bírói ítélet végrehajtása útján történik, amennyiben a törvény a büncselekményre ezt a büntetést állapította meg. 2. Az élettôl való megfosztást nem lehet e Cikk megsértéseként elkövetettnek tekinteni akkor, ha az a feltétlenül szükségesnél nem nagyobb erőszak alkalmazásából ered:a) személyek jogtalan erőszakkal szembeni védelme érdekében;b) törvényes letartóztatás foganatosítása vagy a törvényesen fogva tartott személy szökésének megakadályozása érdekében;c) zavargás vagy felkelés elfojtása céljából törvényesen tett intézkedés esetén.")
} 
nyitotta ki nekik az ajtót. Látta R. G.-t de a többiek arcát nem. Amikor azt kérdezték, miért vannak ellenmondások az előző vallomásaival szemben, a kérelmező kijelentette, hogy zavart lehetett. Megismételte, hogy R.G. 1999. november 28-án ellopta a pénzét, de őt nem bántotta.

2000. április 7-én az ügyész kihallgatta R. G.-t, az azonosított személyt, aki tagadta a büncselekmény elkövetését. Kijelentette, hogy nem ismeri sem a kérelmezőt, sem a házát. Elmondta, hogy egy kicsit ért kurdul, és úgy hallotta, a kérelmező fia azt mondta az anyjának a felismeréskor, hogy őt azonosítsa. Úgy gondolja, mivel ő fél évvel ezelött letartóztatta a kérelmező fiát, talán ő mondta anyjának, hogy azonosítsa azért, hogy bosszút álljon. Megjegyezte továbbá, hogy az elmúlt három és fél évben a környéken dolgozott, és hogy nem mindenki kedvelte. Végül utalt arra a tényre, hogy a kérelmező azonosítás során tett nyilatkozatai ellentétesek a korábbi állításaival.

2000. április 17-én Ş.Y., a Pszichiátriai Osztály igazgatója tájékoztatást adott arról, hogy a kérelmezőtt 2000. február 26-án és március 24-én megvizsgálták. Poszttraumatikus stressz szindrómát diagnosztizáltak nála, és emiatt már akkor kezelés alatt áltt. 2000. május 23-án az ügyész határozatot adott ki arról, hogy nem emel vádat R.G. ellen. A kérelmező kifogásolta a fent említett ügyészi határozatot, de a Bíróság elutasította az ellenvetését. A kérelmező azt állította, hogy a rendőrség továbbra is zaklatta a házában, és hogy 2000 májusában, illetve 2001 áprilisában és júniusában is megverték, illetve megfenyegették. 2005. január 3-án a kérelmezőt letartóztatták. Meghatározatlan időpontban az egyik török bíróság elítélte a kérelmezőt egy illegális fegyveres szervezetnek nyújtott bűnsegély miatt, 3 év 9 hónap szabadságvesztést szabtak ki rá.

Az EJEB 2007. december 11-i döntésében megállapította a 3. Cikk megsértését, mivel nem volt hatékony a nyomozás a kérelmező betegség kezelésével kapcsolatban. (,...lack of an effective investigation into applicant's allegations of illtreatment. $)^{6}$

A Popov Oroszország elleni emberölési alapügyben folytatott nyomozás során a kérelmező részt vett egy felismerésre bemutatáson, ahol négy iskolás fiú közül kettő azonosította. Ám az a két fiú nem is volt szemtanúja a gyilkosságnak, amellyel 2002 májusában meggyanúsították a moszkvai SIZO 77/1-es börtönben tartott kérelmezőt. 2002 júniusában ügyvédje panaszt tett az ügyésznél a nyomozás lefolytatásának módja miatt. Többek között azt állította, hogy a

\footnotetext{
${ }^{6}$ Az ügyben beszerzett orvos szakértői vélemények szerint a kérelmezőnél fennálló poszttraumatikus stressz valószínúleg befolyásolta a valóságnak megfelelő nyilatkozatok tételét, ami nagy valószínűséggel hatással volt a felismerésre bemutatásra is. Tekintve, hogy labilis állapota miatt könnyebben befolyásolhatóvá is vált. Hiba volt, hogy nem az orvos szakértői vélemény előzetes ismeretében végezték el az azonosítást, annak ellenére, hogy az eset részletes leírásából egyértelmü, hogy a kérelmező zavart volt a nyomozás során, így annak befolyásmentes lefolytatása már így nem volt biztosított. Ezt leszámítva is elvégezhető lett volna egy objektív felismertetés, amennyiben az adatgyűjités során az eljáró személyek felfigyelnek arra a tényre, hogy a bemutatott R.G. és a kérelmező fia között egy haragos viszony állt fenn annak letartoztatása miatt. Ez a mulasztás ismét felveti az alapos felkészülés hiányát, amely lehetővé tette a befolyásolt, nem megbízható bizonyítási cselekményt.

${ }^{7}$ Case of Popov v. Russia, No. 26853/04, Judgement 13 July 2006
} 
felismerésre bemutatás megsértette az eljárási követelményeket, és hogy nem tettek lépéseket a kérelmező alibijének igazolására sem.

$A z$ ügyész engedélyezte a védelmi indítvány végrehajtását, hogy tanúként hallgassák ki R-t, a kérelmező szomszédját és K.H-t, a lakásában dolgozó ácsot. Tanúvallomásukat azonban soha nem vették fel a nyomozóhatóságok. 2003-ban a kérelmezőt emberölés miatt tíz év fegyházra ítélték. Az iskolás fiúk ellentmondásos beszámolóján kívül a bíróság más bizonyítékokra is támaszkodott, például az áldozat boncolási jegyzőkönyvére, a büncselekmény helyszínére és különféle egyéb jelentésekre, anélkül hogy megindokolták volna, hogy ezek a tételek miként bizonyították a kérelmező bünösségét.

$A z$ EJEB szerint a védelem két tanúja kihallgatásának mellőzésével a nemzeti bíróság nem mérlegelte, hogy nyilatkozataik fontosak lehettek-e az ügy vizsgálata szempontjából. Azonban abból a tényből, hogy a védelem korábbi indítványait, hogy megvizsgálják őket, mind az előzetes vizsgálat, mind a bírósági eljárás során formálisan többször megadták, ebből az következett, hogy a hazai hatóságok úgy vélték, hogy nyilatkozataik relevánsak lehetnek. Figyelembe véve, hogy:

a) a kérelmező elítélése ellentmondásos bizonyítékokon alapult,

b) a nemzeti hatóságok a tanúk kihallgatását mellőzték,

c) a nyilatkozataik relevanciáját figyelmen kívül hagyták,

d) ezáltal korlátozták a védelemhez való jogot a tisztességes garanciákkal összeegyeztethetetlen módon.

Ezért végső következtetésként az EJEB egyhangúlag megállapította a 6. Cikk (3) bekezdése d) pontjának megsértését a 6 . Cikk (1) bekezdésével összefüggésben.

A Bocos-Cuesta Hollandia elleni ${ }^{8}$ ügyben a kérelmező panaszolta, hogy egy személyes felismerésre bemutatás után a bíróság - helytelenül - visszaküldte az ügyet a nyomozóhatóságnak, hogy a sértettek fényképes felismertetés keretében válasszák ki a bántalmazójukat. A kérelmező kérelmében megfogalmazta, hogy felesleges egy ilyen fajta azonosítást elvégezni az ő fényképével, mert a felismerők korábban már azonosították személyes felismerésre bemutatás keretében (bár nem szabályosan).

Ugyanebben az ügyben fordult elő az is, hogy az eljáró személyek egy olyan detektívtükör segítségével lefolytatott felismerésre bemutatást szerveztek, ahol a gyanúsítotton kívül senki mást nem mutattak be az egymást követő több felismerésre bemutatáson. Továbbá nem engedélyezték semmilyen formáját annak, hogy a kérelmező kérdéséket tehessen fel a kiskorú sértetteknek, a felismerőknek.

A kérelmező azt is sérelmezte, hogy indokolatlanul, ésszerütlen időre elhúzódott az eljárás. Az EJEB megállapította, hogy valóban a nyomozás csaknem két évig folytatódott és ez alatt jelentős késések történtek. A kérelmező 2006 augusztusában már panaszt nyújtott be az ügyészséghez, ám csak 2007. január 10-én hallgatták ki, és hivatalosan csak 2007. január 26-án kezdték meg az érdemi nyomozási cselekményeket. Köztük például csak 2008. február 8-án hajtották végre a felismertetést. A panasz benyújtását követő másfél év utáni foganatosítását semmi sem indokolta. Az EJEB úgy vélte, hogy a nyomozás nem volt átfogó és

\footnotetext{
${ }^{8}$ Case of Bocos-Cuesta v. The Netherlands (Application no. 54789/00) Judgement 5 October 2004
} 
objektív, mindezekre tekintettel megállapította a 6. Cikk (1) és (3) bekezdés d) pontjának megsértését.

Laska és Lika Albánia elleni ${ }^{9}$ alapügyében 2001. március 31-én hajnalban egy kék és két fehér arctakaró maszkot (baklavát ${ }^{10}$ ) viselő személy, Kalasnyikovval és késekkel felfegyverzett személy kirabolta a Kukes és Tirana között közlekedő minibusz utasait. Elvették a sértettek pénzét, ékszereit, majd személyi sérülés okozása nélkül távoztak. Néhány órával később a rendőrök házkutatást végeztek a helyszínhez közeli házakban, beleértve Lika, a második kérelmező házát is, ahol apjával, testvérével (B.L.-lel) és barátjával, Laskával, az első kérelmezővel tartózkodott. A rendőri jelentés szerint a rendőrség az első kérelmező kabátjának zsebében két fehér pólót és egy kék ruhadarabot talált, amelyekből a baklavák készülhettek. (Lopott tárgyakat és az elkövetési fegyvereket nem találták meg, csak a ház mellett néhány gránátot.) A kérelmezőket, és B.L.-t, Lika testvérét, valamint apját a rendőrségre vitték kihallgatásra. B. L. ügyvéd jelenlétét kérte, amit elutasítottak, annak ellenére, hogy ő ekkor még fiatalkorú volt. Lika vitatta, hogy birtokában lett volna bármilyen maszk vagy baklava, és a rendőrséget vádolta a bizonyítékok manipulációjával. Ugyanazon a napon végrehajtották az albán Be. 171-175 §-ai alapján a felismerésre bemutatást a sértettek részvételével. Sorba állítottak öt személyt az azonosítás céljából. A két kérelmező és B.L. kék és fehér otthon készült baklavát viselt, míg a másik két bemutatott személy feketét. Annak ellenére, hogy a rendőrség megváltoztatta a bemutatottak sorban betöltött pozícióját az áldozatok továbbra is a kék és fehér baklavát viselő személyeket azonosította.

A személyek felismerésre bemutatását, tárgyfelismerés követte. Ennek során a sértetteket arra kérték, hogy azonosítsák az elkövetők baklaváit és válasszanak két fekete, két fehér, és egy kék baklava között. A sértettek a fehér és a kék maszkokat választották ki az elkövetők viseletéül. Mindezen bizonyítékok alapján a kérelmezőket és B.L.-t letartóztatták fegyveres rablás gyanúja miatt. Az első kérelmező elfogadta, hogy volt egy fehér póló a birtokában, amely F.N., a nyomozásért felelős rendőr által lett átalakítva baklavává. A második kérelmező viszont azt állította a másik fehér póló, amit az első kérelmezőnél találtak, nem az övé.

2001. április 2-án az ügyészség vádat emelt fegyveres rablás miatt a kérelmezők és B.L. ellen. A tárgyaláson a kérelmezők kérték a bíróságtól a felismerésre bemutatás eredményének figyelmen kívül hagyását, tekintve, hogy az a hazai jogszabályok megsértésével zajlott, illetve meggyanúsították a rendőröket a bizonyítékok meghamísitásával. Ezért kérték is azon rendőrök bíróságra idézését, akik a náluk talált anyagokat baklavának minősítették, ugyanis véleményük szerint azok egyszerü pólók voltak, ezért ezen anyagok bíróság elé szolgáltatását is kérelmezték. A bíróság ezen kérelmeket indokolás nélkül elutasította és a felismerésre bemutatás eredményére alapozva a kérelmezőket fegyveres rablás miatt tizenhárom év, míg B.L.-t öt év szabadságvesztésre ítélte. (Ezen túlmenően

\footnotetext{
${ }^{9}$ Case of Laska és Lika vs. Albánia, (Nos: 12315/04 és 17605/04), Judgement 20 April 2010)

${ }^{10} \mathrm{~A}$ baklava általában egy olyan sapka, mely az egész fejet és nyakat eltakarja és csak a szemet és néha a szájat láttatja.
} 
illegális fegyvertartás vádjában is bünösnek találta őket, annak ellenére, hogy az búncselekmény során az állítólag maguknál tartott fegyvereket nem találták meg a rendőrök.)

2002. május 29-én a vádlottak fellebbezést nyújtottak be a Shkodrai Fellebbviteli Bírósághoz azzal az indokkal, hogy az alapbíróság ítélete tisztességtelen eljárás eredményeként jött létre. Azt állították, hogy az azonosítást az albán Be. 171-175. szakaszának durva megsértésével hajtották végre, mivel ugyanazokat a símaszkokat (símaszk) viselték a felismerésre bemutatás során. Az első fokon eljáró bíróság elutasította ügyvédjeik kérelmét az azonosítással kapcsolatos cselekmények semmisségével kapcsolatban. Azt is sérelmezték, hogy kérésük ellenére a tárgyi bizonyítékok, vagyis a símaszkok egyikét sem mutatták be a tárgyalás során. Azzal is érveltek, hogy a hatóságoknak nem sikerült megtalálniuk a pénzt és a rabláshoz használt fegyvereket sem. Az EJEB előtt a kérelmezők azt kifogásolták, hogy a felismerésre bemutatás tisztességtelen volt. Azt állították továbbá, hogy a hazai bíróságok soha nem tettek eleget kérelmüknek, miszerint a tárgyi bizonyítékokat (símaszkokat) vizsgálják meg az ügy nyilvános tárgyalásain.

Az EJEB érzékelte, hogy a terheltek bünösségét alapvetően (mint legföbb bizonyiték) a felismerésre bemutatás szemtanúinak azonosító vallomásai alapján állapították meg. Ezért külön vizsgálta a felismerés szabályait és végrehajtási módját. Az ítélet szerint az albán Be. 171-175. szakasza egyértelműen szabályozza a felismerésre bemutatás megszervezését. A testület megvizsgálta, hogy a kérelmezők esetében a felismerésre bemutatás lebonyolításának módja összhangban volt-e a 6 . Cikk tisztességességi követelményeivel.

Először is a kérelmezőknek és B. L-nek a sorban kellett állniuk, fehér és kék símaszkokat viselve, hasonló színúeket, mint a büncselekmény elkövetői. A sorban lévő másik két személy fekete símaszkot viselt, ellentétben a kérelmezők és $B$. L. által a büncselekmény elkövetésével vádolt fehér és kék símaszkokkal. A felállításban szereplő személyek helyzetének megváltozása nem eredményezett más eredményt, mivel következetesen ugyanolyan színű (fehér és kék) símaszkokat kellett viselniük. Az EJEB megállapította, hogy a felismerésre bemutatás egyenértékü volt a tanúk nyílt felhívásával arra, hogy a mind a gyanúsítottakra, mind a B. L.-re, mind a búncselekmény elkövetőire rámutassanak. Azt is észlelte az emberjogi Bíróság, hogy a felismerésre bemutatást a kérelmezők ügyvédjeinek távollétében tartották. Az ügy irataiból nem derült $\mathrm{ki}$, hogy a kérelmezők szabad akaratukból - kifejezetten vagy hallgatólagosan - lemondtak-e a védelemre való jogosultságról a felismerésre bemutatáskor. Az EJEB ezzel kapcsolatban megjegyezte, hogy annak ellenére, hogy a kerületi bíróság elismerte, hogy a vizsgálati szakaszban szabálytalanságok történtek, a kérelmezők elítélésekor a kérelmezők pozitív azonosítására támaszkodott, amelyet szemtanúk tettek a felismerésre bemutatás során. Mindazonáltal sem az ügyvéd által utólag nyújtott védelem, sem az azt követő eljárások ellentétes jellege nem tudta orvosolni a bünügyi nyomozás során felmerült hibákat.

Nem volt független felügyeleti eljárás az eljárás tisztességtelensége vagy a kirívó szabálytalanságok elleni tiltakozás miatt sem. A strasbourgi testület 
megállapította, hogy a védelemhez való jog nyilvánvaló figyelmen kívül hagyása ebben a szakaszban visszafordíthatatlanul hátrányosan érintette a későbbi büntetőeljárás igazságosságát.

Végül a döntéshozók megjegyezték, hogy nem volt magyarázat arra, miért utasították el a terheltek azon kérelmét, hogy a felismerésre bemutatás során felhasznált símaszkokat bíróság előtt is bemutassák. Noha igaz, hogy a releváns bizonyítékok nyilvánosságra hozatalának joga nem abszolút, a bíróságnak meg kell vizsgálnia a döntéshozatali eljárást annak biztosítása érdekében, hogy az eljárás a lehetőségekhez mérten megfeleljen a kontradiktórius eljárás, a fegyverek egyenlőségének és az integrált követelményeknek.

Az EJEB úgy ítélte, hogy a kérelmezők ügyének körülményei között a méltányosság azt követelte volna, hogy képessé váljanak arra, hogy érvelhessenek azzal, hogy a felismerésre bemutatás során viselt símaszkok, amelyek a vád döntő bizonyítékát képezték, teljesen mások a rablók által viseltektől. A tárgyaláson azonban nem kaptak lehetőséget arra, hogy orvosolják a felismerésre bemutatás során történt szabálytalanságokat. Ezzel kapcsolatban az albán kormány nem hivatkozott közérdekű indokokra az ilyen bizonyítékok visszatartásában, és a hazai eljárásjogból sem derül ki ilyen ok.

A fenti megállapításokra tekintettel az EJEB arra a következtetésre jutott 2010. április 20-i döntésében, hogy a szóban forgó eljárás nem felelt meg a tisztességes eljárás követelményeinek. Ennek megfelelően kimondta, hogy megsértették a 6 . Cikk (1) bekezdését. ${ }^{11}$

Velev Bulgária ellen ${ }^{12}$ ügyben a kérelmező a hatékony nyomozás elmaradására hivatkozva nyújtott be panaszt. Az alapügyben 2005. március 21-én a kérelmezőt és egy másik személyt, E. Y.-t a rendőrség őrizetbe vette rablás gyanújával. Egy évvel később a kérelmező feljelentést tett, miszerint a rendőrök a három napos őrizetbe vétele alatt megverték azért, hogy rákényszerítsék a büncselekmény beismerésére. Kijelentette, hogy nem tudja a tisztek nevét, de képes lenne azonosítani őket. A kérelmezőt 2007. január és március között többször kihallgatták. Az egyik ilyen alkalommal leírást adott azokról a tisztekről, akik bántalmazták, és azokról is, akik tanúi voltak a támadásoknak. Az egyik rendőr körülbelül $160 \mathrm{~cm}$ magas, fekete hajú, míg a másik rendőr, aki 2005. március 21én bántalmazta 25-30 éves, $175-180 \mathrm{~cm}$ magas, rövid fekete hajú, és jellegzetes alakú szakállal bír.

2008. február 19-én a kérelmező felperes részt vett a fénykép alapú felismerésre bemutatáson. Több fénykép alapján különböző személyeket mutattak neki, a kérelmező pedig ezek közül kettőt azonosított, mint azok a rendőrök, akik 2005. március 21-én megverték, de képtelen volt annak a tisztnek az azonosítására, aki 2005. március 22-én megverte. Később a kérelmezőt D.D.-vel és S.S.-sel szembesítették, ám azt állította, hogy nem ismeri fel őket. Úgy tűnik, hogy nem azok a tisztek voltak, akiket azonosított a korábbi fényképékes felismerésre bemutatáson. 2008. március 11-én az ügyész megszüntette a büntetőeljárást. Ennek egyik oka az volt, hogy a kérelmező beismerte: látta a feltételezett

\footnotetext{
${ }^{11}$ A kérelmezőknek fejenként 4.800 EUR kártérítést állapított meg az EJEB.

${ }^{12}$ Case of Velev v. Bulgaria; Application no. 43531/08. Judgement (Final) 16 July 2013
} 
elkövetőket az eset után, amely az ügyész véleménye szerint befolyásolta a fényképalapú felismerésre bemutatás eredményét.Az EJEB megállapította az egyezmény 3. Cikkének megsértését, mivel a hatóságok hibákat követtek el a kérelmező egészségügyi körülményeinek vizsgálatában. (..."there has been a violation of Article 3 of the Convention by reason of the authorities'failure to investigate the applicant's ill-treatment effectively") $)^{13}$

Beuze Belgium ellenit alapügyében 2007. december 17-én a francia csendőrség Európai elfogatási parancs alapján letartóztatta majd őrizetbe vette és december 31-én átadta a belga hatóságoknak Philippe Beuze (1974) belga állampolgárt, aki előre megfontolt szándékkal megölte volt barátnőjét, M.B.-t. Az elfogatóparancs részletezte, hogy Beuze-t a sértett szomszédja hivatalosan is azonosította. A bünismétlés veszélyének kockázatát is megállapította az elfogatóparancs, a gyanúsított erőszakos előélete okán. A francia csendőrség kihallgatási jegyzőkönyvéből kiderűl, hogy a gyanúsított a francia Be. 63.§. (4) alapján lemondott a védő választásról és a kirendelt védőről is.

A terheltet a belga rendőrség és egy vizsgáló bíró is kihallgatta, védő jelenléte nélkül. Az eljáró belga bíróság elutasította a terhelt kérelmét, hogy a bizonyítékok közül zárják ki azokat, amelyeket védő nélkül vettek fel a rendőrség és a vizsgálóbíró elött. Tárgyalást követően az esküdtszék életfogytiglani fegyházbüntetésre ítélte előre megfontolt szándékból elkövetett emberölés büntettéért. Fellebbezését a legfelsőbb bíróság is elutasította, mivel a tárgyalást megelőző vizsgálati szakaszban a védelem hiányát nem tekintették olyannak, mint ami az eljárás egészét tekintve csorbította volna a tisztességes tárgyaláshoz való jogát.

Az EJEB megállapította, hogy a terheltet 2007. december 31-én 10:40 perckor adták át a belga rendőrségnek, de délután 17:42 percig, azaz a vizsgálóbíróval való találkozásig nem tanácskozhatott a védőjével, amikor is a vizsgálóbíró ügyvéd kirendelését kérte. Ezt követően, bár már szabadon konzultálhatott védőjével, a gyanúsítottat védő jelenléte nélkül hallgatták ki vagy végeztek el egyéb nyomozati cselekményeket, mégpedig tíz esetben. (Köztük a felismertetését is.) A védő a bűncselekmény 2008. június 6-i helyszíni rekonstrukciójában sem vett részt $A z$ egyébként megállapítást nyert, hogy sem a francia, sem a belga hatóságok nem gyakoroltak nyomást a gyanúsítottra.

Az Egyezmény mellett az Európai Parlament és a Tanács 2013/48/EU Irányelve (2013. október 22.) rendelkezik a büntetőeljárás során és az európai elfogatóparancshoz kapcsolódó eljárásokban az ügyvédi segítség igénybevételéhez való jogról, valamint valamely harmadik félnek a szabadságelvonáskor történő tájékoztatásához való jogról, és a szabadságelvonás ideje alatt harmadik felekkel és a konzuli hatóságokkal való kommunikációhoz való jogról. Konkrétan a 3. Cikk. (3). bekezdés c) pontja kimondja:

"a tagállamok biztosítják, hogy a gyanúsítottnak vagy vádlottnak joga legyen ahhoz, hogy ügyvédje legalább a következő nyomozási vagy bizonyitásfelvételı

${ }^{13}$ A kérelmező részére 4.500 euró megfizetésére is kötelezte Bulgáriát az EJEB nem vagyoni kárként és 3.100 euróra pedig költségtérítésként.

${ }^{14}$ No. 71409/10., Judgement 9 November 2018 
cselekményeknél jelen legyen, amennyiben azokat a nemzeti jog elöírja, és amennyiben a gyanúsítottnak vagy a vádlottnak jelen kell lennie vagy jelen lehet: felismerésre bemutatáson, szembesitésen, a büncselekmény rekonstruálásán." Ezért az EJEB ítélete megállapította a 6 . Cikk megsértését, mivel a védő hiánya egyes nyomozási cselekményeknél, mint például a felismerésre bemutatásnál, alááshatja a tisztességes eljárást. ${ }^{15}$

Mindadze és Nemsitsveridze v. Grúzia ${ }^{16}$ elleni alapügyben David Mindadze (továbbiakban első kérelmezö) és Valerian Nemsitsveridze-vel (továbbiakban második kérelmezö) 2005 májusában fordultak az EJEB-hez. Azt állították, hogy:

a) az első kérelmezőt letartóztatásakor a rendőrség bántalmazta,

b) a letartóztatás feltételei és időtartama hiányos és jogellenes volt mindkét személy esetében,

c) egyes őrizetbe vételi határozatok nem voltak megfelelő indokkal ellátva,

d) mindkét kérelmezővel szemben a büntetőeljárás alapvetően tisztességtelen volt.

Az előtörténet szerint 2004 januárjában büntetőeljárás indult ismeretlen személyek ellen, akik K.G. grúziai parlamenti képviselő elleni fegyveres támadást, emberölési kísérletet követtek el. 2004 februárban a sértettet először egy nyomozó hallgatta ki. Leírása alapján a támadóról egy fantomkép készült, de a parlamenti tag azt is elmondta, hogy nem tudja ki volt a támadó (nem ismeri) és nem tudja, hogy képes lenne-e őt felismerni. 2004. május 13-án az első kérelmezőt az utcán fogták el az emberölési kísérlet gyanúja miatt. A rendőrségi jelentés szerint az első kérelmező bevallotta, hogy megegyezett a második kérelmezővel a parlamenti képviselő megölésében, aki ezért tízezer amerikai dollárt ajánlott fel neki. Még mindig ezen a napon az első kérelmező egy felismerésre bemutatáson vett részt három másik személlyel. A parlament tagja egy kis hezitálás után azonosította a kérelmezőt támadójaként.

A felismerésre bemutatás után a parlamenti tag egy privát beszélgetést kért az első kérelmezővel, amit engedélyeztek neki. Senki nem volt jelen a beszélgetésük során, majd szintén ezen a napon a második kérelmezőt is letartóztatták emberölési kísérlet gyanújával. 2004 májusában az első kérelmezőt szembesítették a második kérelmezővel. Ezen a korábbi vallomásának megfelelően vallott, terhelte a második kérelmezőt. Utólag az első kérelmező felesége nyilatkozatában panaszolta, hogy férjén súlyos bántalmazás nyomait vélte felfedezni, ezért 2004 júniusától saját ügyvédet bíztak meg.

Az első kérelmező ezután panaszt nyújtott be a nyomozóhatósághoz, arra hivatkozva, hogy vallomását 2004. május 13-án kínzások hatására tette, megverték és áramütéssel sokkolták. Az akkor készült nyilatkozatok ezen okból nem voltak igazak. Kérte egyúttal az ismételt kihallgatását. Ragaszkodott ahhoz, hogy a

15 Az ítélet utal még más eseti döntésekre is. Lásd Laska és Lika vs. Albánia, (nos. 12315/04 és 17605/04, 20 April 2010 vagy a rekonstruálás körében: (Lásd Savaş v. Turkey (no. 9762/03, 8 December 2009; Karadağ v. Turkey (no. 12976/05) 29 June 2010 és Galip Doğru v.Turkey (no. 36001/06) 28 April 2015

${ }^{16}$ Case of Mindadze and Nemsitsveridze v. Georgia (Application no. 21571/05) Judgement 1 June 2017 
bántalmazása miatt folytatott búnügyi nyomozás döntő fontosságú lenne a jelenleg ellene és a második kérelmező ellen folyó büntetőeljárások megalapozottságának felmérése érdekében.

A második kérelmező szintén ártatlannak vallotta magát. Az ügyvédje kérte, hogy a parlamenti taggal lefolytatott felismerésre bemutatás jegyzőkönyvét nyilvánítsák elfogadhatatlannak, mert azt szabálytalanságok rontják. Ezzel kapcsolatban kiemelte, hogy a sértett azt mondta: nem képes a támadóját azonosítani és a fantomkép, ami az ő leírása alapján készült nem hasonlít az első kérelmezőre. Később ugyan azt állította mégis képes rá, ahogy ezt meg is tette az első kérelmező „általános megjelenésére” alapozva. Ezen felül az első kérelmezőt a sértett előtt három másik emberrel sorakoztak fel, akik teljesen máshogy néztek ki, mint ő. Kérelmét elutasították a grúz hatóságok megalapozatlanságra hivatkozva.

Az egyik férfi, aki részt vett a felismerésre bemutatási sorban, ahol az első kérelmezőt azonosították, elmondta a bíróságnak, hogy a rendőrség véletlenszerüen kereste meg az utcán, hogy vegyen részt benne. Kijelentette, hogy az első kérelmező kivételével, a felismerésre bemutatás mindhárom tagját, beleértve őt is, tisztára borotválták. Egy másik egyértelműen megkülönböztető jellemző az volt, hogy a felállított négy férfi közül csak az első kérelmező volt kopasz. A kérelmező kimerültnek látszott, és az egyik szeme körül mély zúzódás volt. Jelentős különbség volt tehát a kérelmező és többiek megjelenése között.

A felismerésre bemutatási sor másik résztvevője - akit szintén az utcán kerestek meg, hogy vegyen részt - ugyanazon jellemzőket mondta el, mint az előző tanú, beleértve a zúzódást is. Hozzátette, hogy csak az első kérelmezőn nem volt öv és cipőfüző. Amikor a sértett azonosította őt, mint azt az embert, aki rálőtt, a kérelmező felkiáltott, hogy nem ő az.

Ennek ellenére a nemzeti bíróság megállapította, hogy az emberölés kísérletének a vádja bizonyított mindkét kérelmező esetében, méghozzá olyan közvetlen bizonyítékok alapján, amelyeknél nincsenek lényeges anomáliák. Például a parlamenti képviselő magánbeszélgetésével kapcsolatban felvett nyilatkozatai és az első kérelmező nyilatkozatai. Mindkét kérelmező fellebbezést nyújtott be, amelyet a bíróság elutasított és az első kérelmezőt huszonegy, a másodikat tizenhat év szabadságvesztésre ítélték. Az EJEB ítéletében megállapította az Egyezmény 3. §, $5 . \S 1$. és 3 . pontjainak, valamint a $6 . \S 1$. pontjának megszegéseit. ${ }^{17}$

17 Rendőrségi kínzás /torture by the police on 13 May 2004/; letartóztatási jogszerütlenség és érdemi ok nélküli előzetes fogvatartás/unlawfulness of the applicants' pre-trial detention between 13 January 2005 and 7 June 2005/, /absence of sufficient reasons in the detention orders of 10 November 2004 and 7 June 2005/; tisztességtelenség /unfairness of the criminal proceedings against the applicants).Az EJEB megítélt az első kérelmezőnek 28.000, míg a másodiknak 16.000 euró nem vagyoni kártérítést és összesen 4.800 euró költség fedezetet. 


\section{Kutatói válaszok a kezdeti kérdésekre}

a) Az EJEB ismeri és foglalkozik a felismerési cselekménnyel. Leggyakrabban az „identity parade" kifejezést használja az angol nyelvü döntéseiben, határozatainak indokolásában.

b) Egyértelmü, hogy a tisztességes (fair) eljárás követelményét (a 6. Cikket) sértheti, ha a felelősségre vonás alapjául (sokszor nyomatékosan) szolgáló felismerést hibásan (pl. befolyásolóan, kényszerítően) hajtják végre. De felmerülhet a megalázó, meg nem engedett módú kezelés (pl. tortúra) is, ami a 3. Cikk szerinti "kínzás tilalmá"-ba ütközik. A hibás felismerési eredmény, a rossz kiválasztás eredményeként létrejöhet az 5 . Cikkben megfogalmazott „Szabadsághoz és biztonsághoz való jog" megsértése is. És nem kizárt a 8. Cikk megszegése is, ha a módusz behatol a magán- és családi élet tiszteletben tartásához való jogba.

c) Az egyes államoknál előfordul a felismerés kriminalisztikai és büntető eljárásjogi követelményeinek megszegése. A fent leírt esetek mutatják, hogy a nemzeti hatóságoknál vannak szakmai hiányosságok, nem korrekt, nem tisztességes, nem jogszerü végrehajtási formulák.

d) A leggyakoribb megszegési okok között szerepelnek: nem hasonló személyekkel együtt mutatják be a (potenciális) terheltet, hatósági befolyásolások (durvább esetben kényszerítések) történnek, védő értesítése és jelenléte nélkül folytatják le, bizonytalan választást is biztosnak jegyzőkönyveznek.

e) Konkrét felismerési eljárással kapcsolatos magyar kérelmet nem találtunk.

\section{Következtetések, javaslatok}

Az EJEB döntésekből eredő következtetéseink és a magyar jogalkotásnak, jogalkalmazásnak szóló jobbító (fejlesztési) javaslataink vázlatosan a következők. (E sorral válaszolunk a kezdeti hatodik kérdésünkre.)

Kezdjük mindjárt az elnevezési kritikánkkal. Felfogásunk szerint a magyar Be. (2017. XC. tv. 210.§) szerinti „felismerésre bemutatás" szóösszetétel (megnevezés) egyenként és együtt is arra sarkallja az egyébként a hatóságnak is sokszor megfelelni kívánó felismerőt, leggyakrabban a búncselekmény sértett tanúját, hogy a bemutatott személyek (tárgyak, hangok, fényképek, videók stb.) közül válasszon. Hogy mindenképpen válasszon, hogy mindenképpen valakit felismerjen. A megfelelési kényszer pedig azzal a hibás következménnyel járhat, hogy akkor is választ a felismerő, amikor nem is biztos benne, amikor csak hasonlóságot érzékelt, vagy egyszerüen csak a külső jelekből arra következtet, hogy felismerni véli a valós elkövetőt. Tévedése azonban akár justizmordhoz (miscarriage of justice) is vezethet, mivel a kiválasztását cáfolni elméletileg is nehéz, a gyakorlatban pedig szinte lehetetlen, ha nincs a kiválasztottnak érdemi alibi igazolása. Ezért - a bizonyítási kísérlet mintájára - helyesebb lenne "felismerési kísérlet"-ről beszélni, vagyis a felismerés megkísérléséről, semmint bemutatásról. Ezért is szerepeltetjük már ezen kifejezést a tanulmányunk címében. 
Jogalkotási bírálatunk része a következő gondolatunk is. Annak ellenére, hogy a magyar büntető eljárásjogi történetben az eddigi legrészletesebb törvényi szabályozást olvashatjuk a külön nevesített felismerésröl, mégsem mondja ki azt a Be., hogy lehetőleg az eredeti észlelési körülmények között szükséges megtartani a felismertetést.

Szintén de lege ferenda javaslatként vetjük fel, hogy azt is célszerü lenne rögzíteni a törvényi megfogalmazásban, hogy a felismertetést végzőnek fel kell hívnia a felismerőt (ki kell oktatnia):

a) nem biztos, hogy az elkövető a felismerendő személyek között van;

b) nem kötelessége a választás (a mindenáron kiválasztás);

c) akkor is folytatódik a nyomozás, ha nem választ ki senkit;

d) nem fog visszajelzést kapni arról, hogy „helyes" volt-e a választása, ha egyáltalán választ;

e) tárgyak, fényképek felismertetése esetében is alkalmazandó figyelmeztetéseknek kell lennie az a-d) alpontokba foglaltaknak, valamint annak, hogy idő elteltével az elkövető külseje (hajszíne, hajhossza, hajformája, arcszőrzete, bőre) változhat, illetve a fényképeken kissé máshogy nézhet ki.

A jogalkalmazóknak szólóan vetünk fel egy befolyást megelőző javaslatot, egy gyakorlatban is megvalósítható metódust. Ennek során az ügyet ismerő detektívek helyett, az üggyel eddig nem foglalkozott úgynevezett "vak" végrehajtókat vetnek be. Itt olyan bünüldöző (rendőrségi, vámnyomozói, ügyészségi) alkalmazottakról van szó, akik nem ismerik az adott ügyben a (potenciális) gyanúsított személyét, vagyis nem tudják még tudatalattijukban sem, hogy kire irányul a verzió. Magát a sorfalat a gyanúsítottat és az ügyet ismerő kriminalisták állítják össze. Ám szerepük itt egyelőre megáll, kilépnek a processzusból. Átveszi az ügybefolyástól mentes alkalmazott, akinek közölnie is kell ezt a tényt a felismerővel. Mármint, hogy ő csak a felismertetést végzi és az ügyet nem ismeri, csakúgy nem a résztvevőket. Mindezek után lefolytatja - mégpedig kimérten, távolságtartóan, befolyásmentesen, mivel nem is tudja, nem is sejti kire-mire-miért kellene befolyást fókuszálni - a felismerési kísérletet a taktikai-technikai ajánlásoknak megfelelően szervezve, rögzítve. Majd az „eredményt” tartalmazó jegyzőkönyvet átadja az eredeti nyomozóknak. Mivel nincs adata az előzményekről, így nem nehéz teljesíteni a "beugrónak" azt az ajánlást sem, hogy a felismerőknek nem árulhat el semmit, sem megerősítést, sem gyengítést, sem szóban, sem mozdulattal vagy bármiféle metakommunikációval. És ezt nem teheti a felismertetés után sem, mint ahogyan nem tehetik az ügyet ismerő nyomozók sem.

A lefolytatás előtt a (potenciális) gyanúsított jogi képviselöjének (védőjének) célszerü átadni a tanú vagy sértett által adott személyleirást. Ezáltal lehetősége van a kirívóan eltérő, szuggesztív beállítást észrevételezni, szükség esetén panaszolni. Fontos, előzetesen ellenőrizendő kritérium, hogy a sorban álló személyek közül egyik se legyen a felismerő (leggyakrabban a sértett) ismerőse.

A felismerést végzőnek törekedni kell a minél kevesebb kommunikációra a bemutatás alatt. Az instrukcióinak pedig rövidnek, érthetőknek és pontosaknak kell lenni. Taktikai jelentősége lehet annak pontos említése és korrekt rögzítése, hogy a 
felismerő tanú milyen módon fejezi ki azt, hogy a több személy közül kiben ismerte fel azt, akit a büncselekménnyel kapcsolatban észlelt. Rámutat-e, kimondja-e nyíltan, határozottan, bizonyosan, sőt ismételten, avagy ellenkezőleg, bizonytalan, határozatlan.

Az előbbi gondolathoz kapcsolódóan hangsúlyozzuk azon érvelésünket, hogy semmiféle százalékos hasonlóság, egyezőség nem engedhető meg. Vagy felismeri a személyt (tárgyat, hangot) az aktív alany egyértelmüen vagy nem. Köztes, százalékos hasonlítgatásnak nincsen helye, akkor nem beszélhetünk semmiféle azonosításról.

Nézetünk szrint a fontoskodó, hatóságnak megfelelni igyekvő tanú kiszürésére az ún. „üres” formáció kívánatos. Ekkor a csoportba be sem állítják a (potenciális) gyanúsítottat, csak minden gyanú fölött álló, „indifferens" egyéneket.

A tanúkhoz kötődően javasoljuk még, hogy a felismerésekben résztvevő aktív alanyokat (tanúkat, sértetteket) olyan időpontokra célszerü (szeparáltan) idézni a nyomozási cselekményre, hogy egymással ne tudják megbeszélni a korábbi eseményeket, személyeket, leírásaikat sem a hatósági épület előtt, sem a hatósági épületen belül várakozva. Mindent meg kell tenni, hogy egymással ne kommunikálhassanak a felismerés elött, alatt. (PI. nem küldözgethetnek egymásnak mobiltelefonos képeket, sms üzeneteket és nem hozhatnak létre facebook, whatsup csoportot.)

Véleményünk szerint a fényképes azonosításnál mindig több fényképet kell bemutatni a felismerőnek és már ezt kell tenni az előzetes nyomozás adatgyüjtés során is. Azt is kiemeljük, hogy nem mutatható ugyanazon személy többféle (különböző) fényképe. A különböző emberek fényképeinek azonos méretűnek kell lenni és azonos jellemzőkkel is kell rendelkeznie. És mindegyiket ugyanannyi ideig szabad csak bemutatni a felismerőnek. Különösen akkor, ha (részben) funkcionális tulajdonságok (pl. járás, futás, beszéd, hang) alapján történik a személykiválasztás, célszerü a fényképezésnél sokkal modernebb technikai eszközöket (pl. videót, digitális kamerát, elektronikus adatrögzítőt) alkalmazni. Ám semmilyen felvételi összevágásnak, összeollózásnak nincs helye.

Álláspontunk szerint holttest felismerésnél külön kell rögzíteni, ha nem magát a testet, arcot ismerte fel az aktív alany, hanem például a ruházatát vagy ékszerét. Ebben az esetben ugyanis (holt) személyfelismerésről nem beszélhetünk bizonyosan.

Megfontolandónak véljük, hogy tárgyalási szakban szabad-e ismételten feltenni a kérdést a felismerőnek, hogy felismeri-e a személyt, akit már korábban látott és kiválasztott. Nézetünk szerint a "reprodukció reprodukciója” nem igazán bírhat bizonyító erővel.

Végül megemlítjük, hogy nem csak tanú (sértett) védelmi ok, hanem krimináltaktikai (nyomozás érdekü) oka is lehet annak, hogy a passzív alanyok (a felismerendők) nem látják az aktív alanyt, a felismerőt (pl. tanút, sértettet, gyanúsítottat). 


\section{Záró gondolat}

Mint minden jogállamra, biztonságra, minőségi bűnüldözésre, időtálló és szakszerű jogi normákra vágyó ember és minden jogelmélettel foglalkozó kutató, köztük magunk is abban reménykedhetünk, hogy a jövőben van érdemi befolyása és hatása a tudományos publikációk által felvetett javító javaslatoknak a jogalkotásra és a jogalkalmazásra. Ha nem is a következő hónapokban, de évek alatt elérhetjük, hogy a büntetőeljárás egyik sorsfordító szerepet betöltő (főleg nyomozási) aktusa, a felismerési kísérlet mind jogszabályi, mind végrehajtási szinten valóban a perbeli súlyához méltó formában jelenik meg, és nem ad tényalapot téves bírósági döntéshez, mindenki által megelőzendő és kerülendő justizmordhoz.

\section{Irodalomjegyzék}

- Angyal Miklós-Berzsenyi Tamás-Bói László-Farkasné Halász Henrietta -Girhiny KornélNyitrai Endre Tirts Tibor: Tisztjelölt hallgatók a kriminalisztikai megismerés startkövénél (egy szimulált baleset tanulságai) Magyar Rendészet, 2017/2. 27-66.

- Anti Csaba László (szerk.): A személyleírás. Semmelweis Kiadó és Multimédia Stúdió Kft, Budapest, 2017.

- Anti Csaba: A felismerésre bemutatás főbb elméleti kérdése. Magyar Rendészet,2007/12.107-116.

- Badó Attila-Bóka János: Ártatlanul halálra ítéltek. Az amerikai igazságszolgáltatás tévedései. Nyitott Könyv Kiadó, Budapest, 2003.

- Behrman, B. W.-Davey, S. L.: Eyewitness identification in actual criminal cases: an archival analysis. Law and Human Behavior, 2001/5. 475-491. https://doi.org/10.1023/A:1012840831846

- Collins, J. M.-Jarvis, J.: The Wrongful Conviction of Forensic Science. Forensic Science Policy and Management, 2009/1. 17-31. https://doi.org/10.1080/19409040802624067

- Czinege Kinga: Felismerésre bemutatás és annak hibái mint justizmord Studia iuvenum iurisperitorum, 2014/7. 369-388.

- Denov, M. S. .-Campbell, K. M.: Criminal Injustice Understanding the Causes, Effects, and Responses to Wrongful Conviction in Canada. Journal of Contemporary Criminal Justice, 2005/3. 224-249. https://doi.org/10.1177/1043986205278627

- Elek Balázs: A vallomás befolyásolása a büntetőeljárásban. Tóth Könyvkereskedés és Kiadó Kft., Debrecen, 2008.

- Farkas Ákos-Róth Erika: A büntetőeljárás. Wolters Kluwer Kft., Budapest, 2018.

- Fázsi László: A felismerésre bemutatás szabályainak jelentősége a nyomozás eredményének bírói értékelésekor. Belügyi Szemle, 1997/9. 104-107.

- Fenyvesi Csaba: Fénykép-, videó-, hang-, tárgyfelismerési kísérlet a magyar bíróságok döntéseiben. Ügyészek Lapja, 2021/1-2. 17-32.

- Fenyvesi, C.: Forensische Fehler und Justizirrtümer. Kriminalistik, 2018/2. 67-72.

- Garrett, B. L.: Convicting the Innocent: Where Criminal Prosecutions Go Wrong. Cambridge, Masschusetts - London, Harvard University Press, 2011. https://doi.org/10.4159/harvard.9780674060982

- Hack Péter: Az igazságszolgáltatás kudarcai. In: Fenyvesi Csaba (szerk.): A Magyar Büntetőjogi Társaság Jubileumi Tanulmánykötete. MBT, Budapest- Debrecen-Pécs, 2011.

- Handrik Adél: A justizmordok okai - tévedési források a büntetőeljárásban. Belügyi Szemle, 2011/9. 41-63. 
- Huff, C. R.-Rattner, A.- Sagarin, E.: Convicted But Innocent. Wrongful Conviction and Public Policy. Sage Publications, Thousand Oaks, 1996.

- Kollár Balázs: A felismerésre bemutatás elmélete és gyakorlata Amerikában. Belügyi Szemle, 2013/10. 94-109.

- Korinek László: Az ártatlanság félelme. Jogtudományi Közlöny, 2017/7-8. 309- 321.

- Kovács Lajos: A Mór megtette... Korona Kiadó, Budapest, 2009.

- Levi, A. M.: Some Facts Lawyers Need To Know about the Police Lineup. Criminal Law Quaterly, 2002/46. 176-184.

- Lindsay, R. C. L.-Wells, G. L.: Improving eyewitness identification from lineups: Simultaneous versus sequential lineup presentation. Journal Applied Psychology, 1985/70. 3. 556-564. https://doi.org/10.1037/0021-9010.70.3.556

- Loftus, E. F.: Eyewitness testimony . Harvard University Press, Boston, 1996. https://doi.org/10.1007/978-1-349-24483-6_46

- Malpass R. S.: A policy evaluation of simultaneous and sequental lineups. Psyhology Public Policy, and Law 2006/12. 4. 394-418. https://doi.org/10.1037/1076-8971.12.4.394

- Malpass, R. S.: Effective Size and defendant bias in eyewitness identification lineups. Law and Human Behavior,1981/5. 299-309. https://doi.org/10.1007/BF01044945

- Meteňko, J. : Kriminalisticka taktika. Akadémia Policajného Zboru v Bratislave, Bratislava, 2012.

- Nolan, F.: A recent voice parade. International Journal of Speech, Language, Law, 2003/10. 277-291. https://doi.org/10.1558/sll.2003.10.2.277

- Odenthal, H. J.: Die Gegenüberstellung im Strafverfahren. Richard Boorberg Verlag, Stuttgart-München-Hannover-Berlin-Weimar, 1992.

- Peters, K.: Fehlerquellen im Strafprozess. Eine Untersuchung der Wiederaufnahmeverfahren in der Bundesrepublik Deutschland. 2. Band. Verlag C. F. Müller, Karlsruhe, 1972.

- Roberts, S. (2003): Unsafe convictions. Defining and compensating miscarriages of Justice. Modern Law Review, 2003/3. 441-454. https://doi.org/10.1111/14682230.6603007

- Scheck, B.-Neufield, P. J.-Dwyer, J.: Actual Innocence: Five Days to Executions and other Dispatches from the Wrongly Convicted. Doubleday, New York, 2000.

- Spinney, L.: Line-ups on trial. Nature, 2008. i.453. 442-444. https://doi.org/10.1038/453442a

- Stridbeck, U. -Magnussen, Ph., S.: Prevention of Wrongful Convictions: Norwegian Legal Safegauards and the Criminal Cases Review Commission. Cincinatti Law Review, 2013/4. 1373-1390.

- Wall, P. M.: Eye-Witness Identification in Criminal Cases. Charles C. Thomas Publisher, Springfield, Illionois, USA, 1965.

- Wells, G. L.: The psychology of lineup identifications. Journal of Applied Social Psychology 1984/2. 89-103.

https://doi.org/10.1111/j.1559-1816.1984.tb02223.x

- Wójcikiewicz J.: Forensics and Justice. Dom Organizatora. Torun, 2009. 